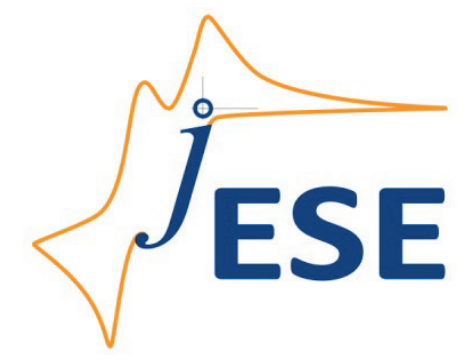

Open Access : : ISSN 1847-9286

www.jESE-online.org

Original scientific paper

\title{
Removal of arsenic and COD from industrial wastewaters by electrocoagulation
}

\author{
S. ZODI, O. POTIER, C. MICHON, H. POIROT, G. VALENTIN, J. P. LECLERC and \\ F. LAPICQUE ${ }^{\square}$ \\ Laboratoire Réactions et Génie des Procédés, CNRS - Nancy Université , ENSIC- BP 20451, \\ F-54001 Nancy, France
}

Corresponding Author: +33 0383175 266, francois.lapicque@ensic.inpl-nancy.fr

Received: March 21, 2011; Revised: May 09, 2011; Published: August 20, 2011

\begin{abstract}
The paper deals with the treatment of arsenic-containing industrial wastewaters by electrocoagulation. The waste issued from a paper mill industry downstream of the biological treatment by activated sludge was enriched with arsenic salts for the purpose of investigation of the treatment of mixed pollution. First, the treatment of single polluted waters, i.e. containing either the regular organic charge from the industrial waste or arsenic salts only, was studied. In the case of arsenic-containing waters, a broad selection of experimental data available in the literature was compiled and interpreted using an adsorption model developed previously. The same technique was used in the case of industrial waste. Arsenic-enriched paper mill wastewaters with various amounts of As salts were then treated by electrocoagulation with Fe electrodes. The set of data obtained were interpreted by a model developed on the basis of the separate models. The agreement between predicted and experimental variations of the As concentrations ranging from $0.3 \mu \mathrm{g} / \mathrm{L}$ to $730 \mu \mathrm{g} / \mathrm{L}$ showed that both the organic matter and As salt can be removed from the liquid independently from each other.
\end{abstract}

\section{Keywords}

Electrocoagulation; industrial wastewaters; arsenic; adsorption model

\section{Introduction}

Arsenic (As) is one of the most toxic elements that can be present in wastewaters and environment in general. Therefore, the treatment of groundwater has been investigated for decades for the possible use of existing water stocks with appreciable As contents [1], in particular of those close to the mines, as reported by Leist et al. [2]. 
Treatment of As-containing solutions, being of natural origin or prepared by dissolving chemicals in pure water, has been tackled for years. It seems that As compounds - particularly those in the pentavalent form - exhibit interesting sorption capacities on Fe(III) hydroxides. Adsorption also occurs on $\mathrm{Al}(\mathrm{III})$ hydroxides, although not as strongly as on Fe(III) species $[1,3,4]$. Coagulation and electrocoagulation, therefore, seem interesting and suitable methods for the treatment of arsenic-containing species. The two treatment techniques do not differ very much. In both cases, the treatment consists of two steps: (i) supply of the liquid to be treated with Fe(III) species, either by Fe electrode dissolution to Fe(II) and subsequent oxidation to Fe(III) upon air oxidation or by addition of Fe salts, (ii) complexation-adsorption of As species on Fe(III) species. Since the treatment is often carried out at $\mathrm{pH}$ above 3, trivalent Fe species are in the form of solid hydroxide $\mathrm{Fe}(\mathrm{OH})_{3}$.

The largest part of research on this subject has been focused on potabilization of water $[2,3,5,6]$. Although the content of As-salts in the analyzed waters was as large as $100 \mathrm{mg} / \mathrm{L}$, the chemical oxygen demand (COD) content of the solutions to be treated was very low and the presence of other species could be disregarded. In this study, we investigated the electrocoagulation treatment of As-containing industrial wastes for abatement of the COD and As species by using dissolution of iron anodes. Electrocoagulation technique relies on the destabilization of suspended matter by reduction of the absolute value of the zeta potential by the presence of electrogenerated trivalent metals. This technique has been used in and investigated for the treatment of various wastewaters $[1,3,5,7,8]$. The waste generated from paper mill industry has a slight arsenic content at ppb level. The addition of arsenic salts to the original waste makes it possible to investigate the treatment of mixed wastewaters. For this purpose, the published data on the treatment of single solutions of arsenic salts were compiled and analyzed using a simple model for electrocoagulation published previously [9] and relying upon two parameters. Moreover, the treatment of the industrial wastewater with negligible concentrations of As allowed for the estimation of the two parameters related to the COD abatement. Numerous electrocoagulation tests with the waste after the addition of various amount of As species were conducted. The interpretation of the data was made taking into account the presence of the two pollutants to examine whether the presence of As could affect COD removal in the electrocoagulation process, as it has been observed in the case of $\mathrm{Cr}$-containing industrial solutions [7].

\section{Experimental}

\section{Wastewater samples and chemicals}

The wastewater was collected from a local paper mill industry (Clairefontaine, France) downstream of a primary settling stage and biological treatment by activated sludge. The waste already used in the previous investigation [10] had $\mathrm{pH}=7.7, \mathrm{COD}=285 \mathrm{mg} \mathrm{O} / \mathrm{L}$, turbidity = $35 \mathrm{NTU}$, and a very low As content near $3.8 \mu \mathrm{g} / \mathrm{L}$. The COD level was mainly due to the presence of dissolved or suspended organic matters. Because of the relatively high conductivity of the wastewater, $1.22 \mathrm{mS} \mathrm{cm}^{-1}$, no supporting electrolyte, such as sodium chloride, had to be added.

The concentration of arsenic species was enhanced by adding small amounts of arsenic acid disodium salt, $\mathrm{Na}_{2} \mathrm{HAsO}_{3}$ (Purissimum, Fluka), to the wastewater. Arsenic concentration in the wastewater obtained was below $1 \mathrm{mg} / \mathrm{L}$. The moderate COD of the industrial waste allows to have a reasonable organic pollution to As pollution ratio, so that interactions between As and the organic pollution could be investigated.

\section{Electrochemical reactor}

Treatment runs have been carried out batchwise by recirculation of 2.5 liters wastewater in the flow rig consisting of a reservoir tank, peristaltic pump, flow meter, and an electrochemical cell 
$[9,10]$. The electrochemical cell had a rectangular cross-section and was provided with two flat facing Fe electrodes, being $15 \times 7 \mathrm{~cm}^{2}$. The electrode gap was maintained at $2 \mathrm{~cm}$ and the liquid was circulated at $300 \mathrm{~cm}^{3} \mathrm{~min}^{-1}$.

Runs were carried out for periods of time ranging from 45 to 90 minutes, depending on the current density applied, which ranged between 5 and $20 \mathrm{~mA} \mathrm{~cm}{ }^{-2}$. The cell voltage was monitored along the run..

\section{Pollutants analysis and quantification}

Liquid fractions of $10 \mathrm{~cm}^{3}$ were collected at regular intervals along the runs. The concentration values of the various species were corrected for the change in the liquid volume caused by the regular sampling. Conductivity and $\mathrm{pH}$ were monitored using a multi-parameter instrument (Consort C931). A small volume of each sample was acidified by nitric acid in order to determine the Fe and As concentrations by ICP-MS (Series X7, Thermo) after suitable dilution of the acidic solution. For arsenic species, a small liquid volume was submitted to microwave digestion using a START-D instrument prior to injection to the ICP-MS instrument.

The rest of each sample was allowed to settle for at least twelve hours before the analysis of the clear fraction was carried out. The turbidity was measured using an IR beam at $890 \mathrm{~nm}$ and detection of the light dispersion using a Hanna Ins. LP2000 spectrophotometer, and COD was determined by the standardized colorimetric method after high temperature oxidation with excess chromic acid and subsequent measurement of the optical density at $530 \mathrm{~nm}$ using a HACH 2400 spectrophotometer. The estimated accuracy in the COD measurement was $25 \mathrm{ppm}$.

\section{Electrocoagulation of the industrial waste}

The industrial waste with a low content of As species was submitted to electrocoagulation at two levels of the current density. As expected, the COD level was observed to decrease regularly with time in spite of the slight scattering of the data due to the uncertainty in the assay. Moreover, electrocoagulation did not allow the entire removal of the organic charge since the final COD level was usually at approximately $50 \%$ of the initial value, even upon longer electrocoagulation runs. The concentration of dissolved iron increased regularly during the run. The overall current yield of the dissolution at time $t$ was calculated as follows:

$$
\Phi_{\mathrm{Fe}}=\frac{[\mathrm{Fe}(\mathrm{III})]_{t} V n_{\mathrm{Fe}} F}{M_{\mathrm{Fe}} A i t}
$$

where $V$ is the volume of the wastewater under treatment, $n_{F e}$ the number of electrons involved in the dissolution, taken as 2 because the anode dissolution leads to Fe(II) species, which rapidly oxidizes to $\mathrm{Fe}(\mathrm{III})$ in the presence of air oxygen. In equation (1), $M_{\mathrm{Fe}}$ is the molecular weight of iron, $i$ the current density applied, and $A$ the geometrical area $\left(105 \mathrm{~cm}^{2}\right)$. The current yield was observed to increase slightly over time, from 0.5 in the first minutes and reaching 0.8-0.85 after 30-40 minutes. This could be caused by partial inhibition of the iron electrode immersed in the liquid in the early stage of the run, as the electrode probably exhibited only moderate corrosive properties.

As often reported, the reduction in COD level is mainly governed by the amount of coagulant generated at the anode surface (Fig. 1). The experimental variation was modeled using a previous overall model [11] relying upon the instantaneous adsorption or complexation of the pollutant charge - expressed by the COD - with Fe(III) hydroxide. The presence of As species below $4 \mu \mathrm{g} / \mathrm{L}$ was neglected here.

$\mathrm{Fe}(\mathrm{III})$ complexes organic matter, expressed by the COD level, S, as follows:

$$
\mathrm{Fe}(\mathrm{III})+n_{1} \mathrm{~S} \leftrightarrow \mathrm{FeS}
$$


where coefficient $n_{1}$ is expressed in $\mathrm{mg} / \mathrm{L} \mathrm{O}_{2}$ per $\mathrm{mg} / \mathrm{L}$ Fe species, since $\mathrm{S}$ is expressed by the COD level. For the sake of simplicity, the complex formed in the treatment is written FeS, regardless of $n_{1}$ value. In this section, Fe(III) and S represent free species. It can be observed at this level that numerous unknown elementary processes are involved in the overall treatment. Moreover, it is not clear whether the abatement of the pollutant is governed only by absorption and what are the molecular structures of coagulants and pollutants. Because of this, we defined a simplified apparent equilibrium constant $K_{1}$ simply written as:

$$
K_{1}=\frac{[\mathrm{FeS}]}{[\mathrm{Fe}][\mathrm{S}]} \quad(\mathrm{in} \mathrm{L} / \mathrm{mg})
$$

where coefficient $n_{1}$ is expressed in $\mathrm{mg} / \mathrm{L} \mathrm{O}_{2}$ per $\mathrm{mg} / \mathrm{L}$ Fe species, since $\mathrm{S}$ is expressed by the COD level. For the sake of simplicity, the complex formed in the treatment is written FeS, regardless of $n_{1}$ value. In this section, $\mathrm{Fe}(\mathrm{III})$ and $\mathrm{S}$ represent free species. It can be observed at this level that numerous unknown elementary processes are involved in the overall treatment. Moreover, it is not clear whether the abatement of the pollutant is governed only by absorption and what are the molecular structures of coagulants and pollutants. Because of this, we defined a simplified apparent equilibrium constant $K_{1}$ simply written as:

$$
\begin{aligned}
& {[\mathrm{S}]_{0}=[\mathrm{S}]+\frac{[\mathrm{FeS}]}{n_{1}}} \\
& {[\mathrm{Fe}]_{t}=[\mathrm{Fe}]+[\mathrm{FeS}]}
\end{aligned}
$$

where $[S]_{0}$ expresses the initial COD level, and $[\mathrm{Fe}]_{t}$ represents the concentration of the generated $\mathrm{Fe}$ (III) covering both free and complexed Fe(III) forms. As a matter of fact, a fraction of the pollutant matter with the concentration $[S]_{f}$ cannot be treated, so only fraction $\left([S]-[S]_{f}\right)$ has to be considered in the adsorption equilibrium constant. Equations (2)-(5) led to the expression for the untreated S concentration:

$$
[\mathrm{S}]=[\mathrm{S}]_{\mathrm{f}}+\frac{-\left(\frac{[\mathrm{Fe}]_{\mathrm{t}}}{n_{1}}-\left([\mathrm{S}]_{0}-[\mathrm{S}]_{\mathrm{f}}\right)+\frac{1}{K_{1}}\right)+\sqrt{\left(\frac{[\mathrm{Fe}]_{t}}{n_{1}}-\left([\mathrm{S}]_{0}-[\mathrm{S}]_{\mathrm{f}}\right)+\frac{1}{K_{1}}\right)^{2}+\frac{4\left([\mathrm{~S}]_{0}-[\mathrm{S}]_{\mathrm{f}}\right)}{K_{1}}}}{2}
$$

Fitting of the experimental variation of the COD led to the estimates for $K_{1}$ and $n_{1}$, even though a narrow-valley situation in the optimization procedure was encountered. As formerly observed in the treatment of other industrial wastes [12], moderate COD levels in relation to ratio $\left(K_{1} / n_{1}\right)$ resulted in the higher accuracy obtained in determination of the ratio. Nevertheless, the two parameters could be estimated at $n_{1}=2.1 \mathrm{mg} \mathrm{O}$ per $\mathrm{mg} \mathrm{Fe}$, and $K_{1}=0.029 \mathrm{~L} / \mathrm{mg}$ (Fig. 1).

\section{Electrocoagulation of pure solutions of arsenic salts}

Before the compilation of published experimental data on As removal by electrocoagulation from waters possessing very low COD or turbidity levels, physicochemical properties of arsenic salts are briefly discussed. 


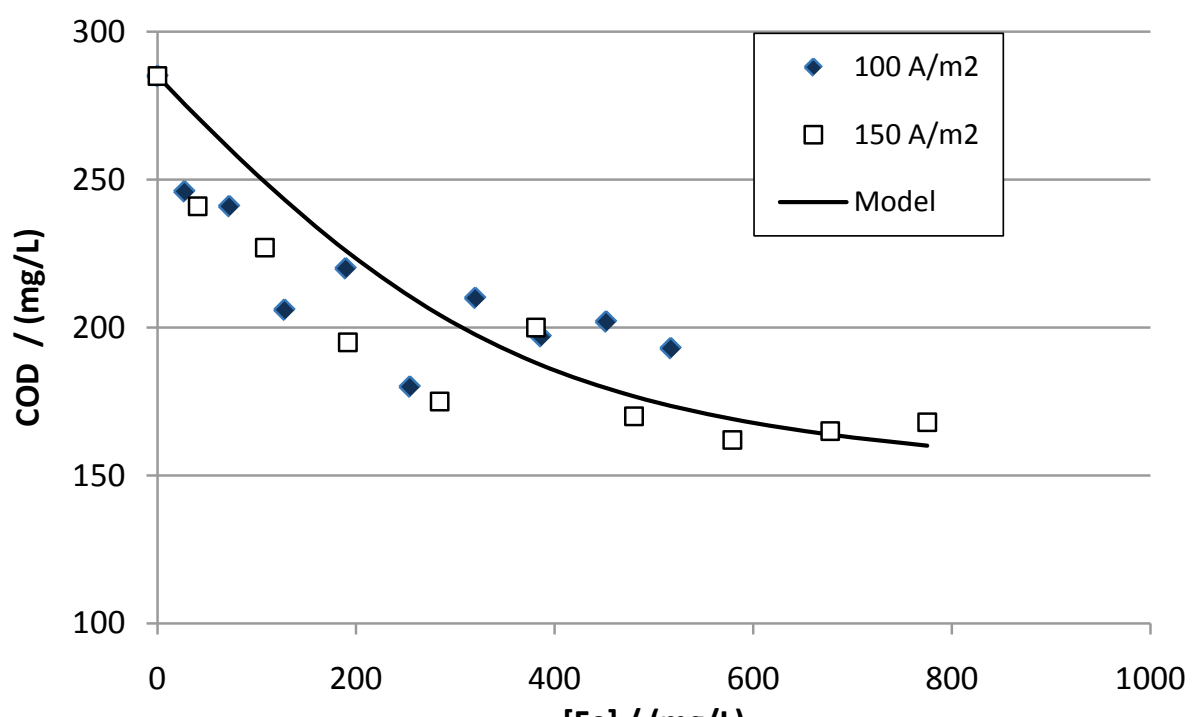

Figure 1. COD abatement from the industrial waste. The model considered is expressed by rel. (4)

\section{General features of As species in wastewaters}

Arsenic can be encountered in the form of either organic compounds with methyl groups or inorganic species. The most stable forms in ores or waste are arsenious salts (the trivalent form) and arsenate salts (pentavalent form). As(III) form is obtained from arsenious acid, $\mathrm{HAsO}_{2}$, or its hydrated form, $\mathrm{H}_{3} \mathrm{AsO}_{3}$ [13]. The two acids exhibit weak acidity, with a pKa near 9.2. As(V) is obtained from arsenic acid, $\mathrm{H}_{3} \mathrm{AsO}_{4}$. The acidity constants of the triacid are near 2.25, 6.77, and $11.60[8,14]$. Therefore, for electrocoagulation of As-containing wastewater with an initial pH near 7 and increasing up to 9 in the course of the treatment, As mainly has the following forms: $\mathrm{H}_{3} \mathrm{AsO}_{3}$ with slight amounts of $\mathrm{H}_{2} \mathrm{AsO}_{3}{ }^{-}$for $\mathrm{As}(\mathrm{III})$ and $\mathrm{H}_{2} \mathrm{AsO}_{4}{ }^{-}$and $\mathrm{HAsO}_{4}{ }^{2-}$ ions for $\mathrm{As}(\mathrm{V})$. The latter two species are prone to adsorption on Fe(III) hydroxide $[15,16]$.

Pentavalent salts might be considered as oxidants, i.e. existing at appreciable extent under oxidizing conditions. Pentavalent arsenic is in equilibrium with As(III) according to:

$$
\mathrm{H}_{3} \mathrm{AsO}_{4}+2 \mathrm{H}^{+}+2 \mathrm{e}^{-} \leftrightarrow \mathrm{HAsO}_{2}+2 \mathrm{H}_{2} \mathrm{O} \quad \mathrm{E}_{0}=0.560 \mathrm{~V}
$$

Considering a solution with a $\mathrm{pH} 7$, the equilibrium potential deduced from Nernst law is 0.147 $\mathrm{V} / \mathrm{NHE}$. From a thermodynamic point of view, $\mathrm{As}(\mathrm{V})$ and $\mathrm{As}(\mathrm{III})$ can be present in most aqueous media. It is generally admitted that $A s(V)$ is a predominant form in waters provided sufficient aeration.

The iron anode dissolves to Fe(II). This reducing species can oxidize to Fe(III) according to:

$$
\mathrm{Fe}^{2+} \leftrightarrow \mathrm{Fe}^{3+}+\mathrm{e} \quad \mathrm{E}_{0}=0.771 \mathrm{~V}
$$

Comparison of the equilibrium potentials of the redox couples shows that $\mathrm{As}(\mathrm{V})$ cannot be reduced by $\mathrm{Fe}(\mathrm{II})$; the latter rapidly oxidizes to $\mathrm{Fe}(\mathrm{III})$ by air oxygen in aerated media.

Nevertheless, removal of As by adsorption or electrocoagulation is more efficient for $A s(V)$ than $\mathrm{As}(\mathrm{III})$. In addition to its lower intrinsic toxicity, $\mathrm{As}(\mathrm{V})$ is thus a less hazardous form of arsenic to be used for treatment or consumption purposes. For this reason, in most investigations, pretreatment of wastewaters includes the preliminary step of $\mathrm{As}$ (III) oxidation using hydrogen peroxide, Fe(III), or at the anode surface, as reported by Ratna Kumar et al. [4].

Application of the electrocoagulation model to As removal

The model was directly derived from that for COD abatement. Fe(III) complexes As species as follows: 


$$
\mathrm{Fe}(\mathrm{III})+n_{2} \mathrm{As}(\mathrm{V}) \leftrightarrow \mathrm{FeAs}
$$

where coefficient $n_{2}$ is expressed in mg Fe(III) per mg As species. Equilibrium constant $K_{2}$ is simply written as:

$$
K_{2}=\frac{[\mathrm{FeAs}]}{[\mathrm{Fe}][\mathrm{As}]} \quad(\text { in L/mg) }
$$

Langmuir's model has been used in several investigations for modeling the adsorption equilibrium of As species on Fe(III) hydroxide. Mass balances on Fe and As species were also written:

$$
[\mathrm{As}]_{0}=[\mathrm{As}]+\frac{[\mathrm{FeAs}]}{n_{2}}
$$

From the equations (10-12), the concentration of complex FeAs can be expressed as follows:

$$
[\mathrm{FeAs}]=\frac{K_{2}[\mathrm{Fe}]_{t}[\mathrm{As}]}{1+\frac{K_{2}}{n_{2}}[\mathrm{As}]}
$$

which appears perfectly similar to the conventional Langmuir's expression

$$
q_{\mathrm{As}}=\frac{K_{\mathrm{L}}[\mathrm{As}]}{1+a_{\mathrm{L}}[\mathrm{As}]}
$$

where $q_{A s}$ is the amount of As adsorbed on Fe hydroxides, the binding constant $K_{L}$ can be related to product $K_{2}[\mathrm{Fe}]_{\mathrm{t}}$, and the sorbent capacity $a_{L}$ to the ratio $\left(K_{2} / n_{2}\right)$.

As with $\mathrm{S}$, the concentration of free, untreated arsenic species is obtained by solving the system formed byequations (10-13):

$$
[\mathrm{As}]=\frac{-\left(\frac{[\mathrm{Fe}]_{t}}{n_{2}}-[\mathrm{As}]_{0}+\frac{1}{K_{2}}\right)+\sqrt{\left(\frac{[\mathrm{Fe}]_{t}}{n_{2}}-[\mathrm{As}]_{0}+\frac{1}{K_{2}}\right)^{2}+\frac{4[\mathrm{As}]_{0}}{K_{2}}}}{2}
$$

As relevant studies indicate, $\mathrm{As}(\mathrm{V})$ species can be totally removed by electrocoagulation; therefore, its final concentration $[A s]_{f}$ was neglected here. The model was applied to various data reported in the literature $[1,4,15,17]$. Because the corresponding values for the concentration of generated iron species were rarely reported, it was assumed that iron anodes dissolved with a current efficiency equal to 0.8 , as observed in previous investigations $[9,10]$. The postulated value is also in fair agreement with the value observed for the treatment of the industrial waste (see above section). The various data considered were approximately fitted to the model, yielding estimates for constants $K_{2}$ and $n_{2}$.

Fig. 2 shows the good correlation between theory and experimental data for As concentrations ranging from $100 \mu \mathrm{g} / \mathrm{L}$ to $30 \mathrm{mg} / \mathrm{L}$ within a factor 2 , with

$K_{2}=1.12 \mathrm{~L} / \mathrm{mg}$ and $n_{2}=1.82 \mathrm{mg}$ Fe per $\mathrm{mg}$ As 


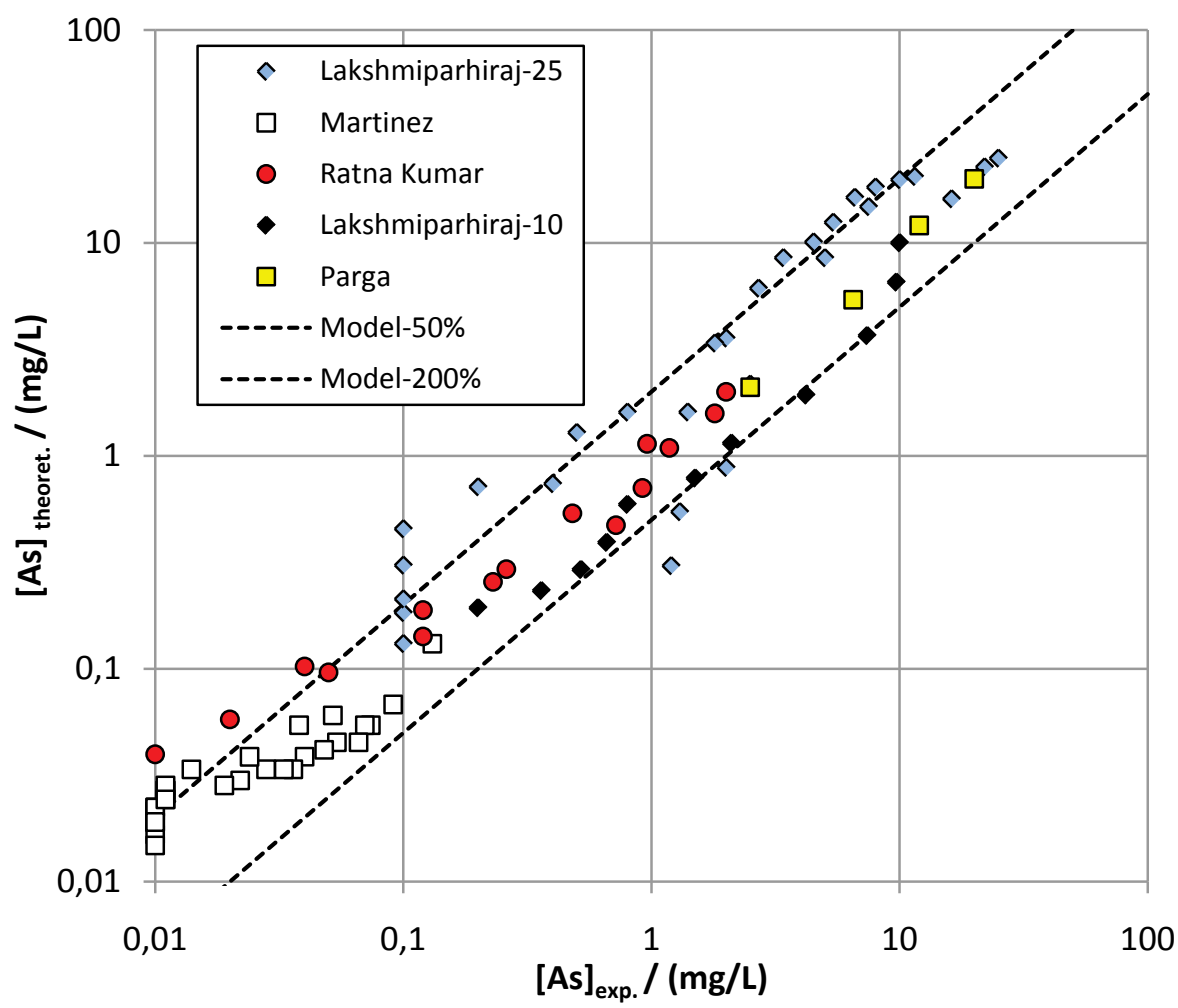

Figure 2. Validation of the model for adsorption of As species onto Fe hydroxide (rel. 15): data issued from refs. [1], [4], [15] and [17] are related to treatment of synthetic As solutions or groundwater. The dotted lines correspond to $50 \%$ and $200 \%$ of the diagonal expressing perfect agreement between the model and experiments.

The existing scattering of the data is probably due to the lack of accuracy in the estimation of coagulant concentration. Simulation tests actually showed that Fe(III) concentration had a noticeable impact on the predicted concentration of remaining As species. Besides, the value for $n_{2}$ could not be compared directly to the molar Fe/As ratio values reported in the literature and discussed by Hansen et al. [3], because the adsorption of As species, like other pollutants, obeys an adsorption isotherm law involving equilibrium between complexed and free species. Therefore, the parameter $n_{2}$ does not correspond to the Fe/As ratio, which is deduced by global assessment of As removal depending on the amount of Fe(III) generated.

\section{Removal of As-containing industrial waste}

\section{Experimental observations}

Numerous batch runs have been carried out with As concentrations up to $700 \mu \mathrm{g} / \mathrm{L}$. In most cases, iron dissolution in the industrial waste was shown to be unaffected by the presence of the arsenic salt (Fig. 3). The concentration in Fe species in the liquid increased regularly with the electrical charge passed, although at a slower dissolution rate in the first minutes of the run. This corresponds to the increase in current yield mentioned in a previous section with the raw industrial waste. In addition, the concentration of arsenic salt decreased with time. As for the COD and other features of the wastewater under treatment, the abatement of the toxic As-additives is governed by the amount of Fe dissolved (Fig. 4). Nevertheless, removal of As(V) species is nearly complete with $150 \mathrm{mg} / \mathrm{L}$ Fe dissolved, whereas the removal of the organic matter requires more significant dissolution (Fig. 1). 


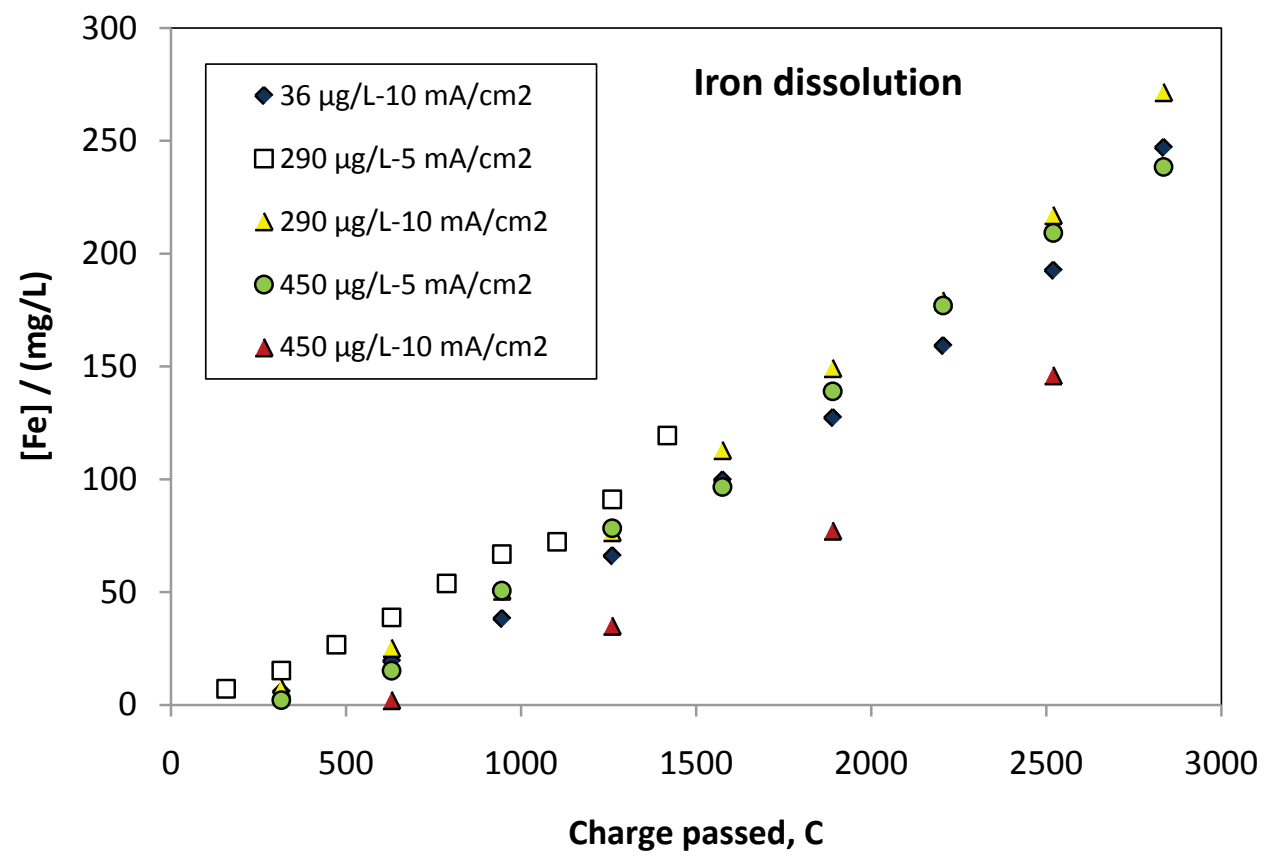

Figure 3. Anode iron dissolution in the treatment runs for various concentrations of $A s$ in the enriched paper mill wastewater.

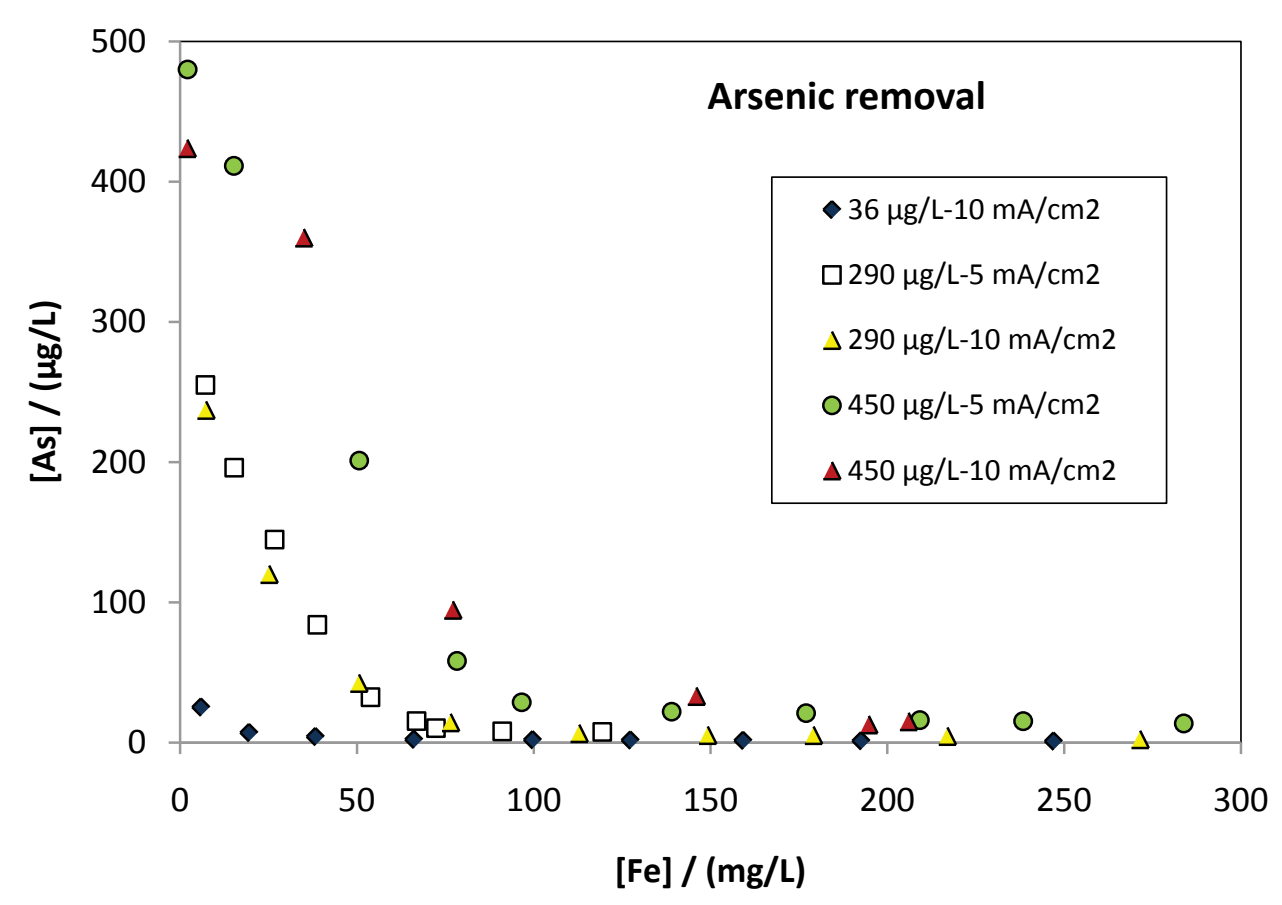

Figure 4. Typical variations of As species concentrations with the amount of dissolved iron in treatment runs of the As-enriched paper mill wastewater depending of operating conditions.

\section{Modeling of As-removal from the industrial waste}

Treatment of As-containing wastewaters was modeled assuming that the generated coagulant acts independently on the organic matter and $\mathrm{As}(\mathrm{V})$ species. S adsorbs on Fe(III) hydroxide according to parameters $\left(K_{1}, n_{1}\right)$, whereas $\mathrm{As}(\mathrm{V})$ adsorbs on the solid coagulant with parameters $\left(K_{2}, n_{2}\right)$. The model was, therefore, developed on the basis of equilibrium (2) and (8) with constants $K_{1}$ and $K_{2}$. Mass balances were written for the pollutant charge expressed by $\mathrm{S}$, as well as for $\mathrm{As}(\mathrm{V})$ and Fe(III). The two first balances are given in equations (4) and (11), respectively, whereas the conservation of Fe species is written as: 


$$
[\mathrm{Fe}] \mathrm{t}=[\mathrm{Fe}]+[\mathrm{FeS}]+[\mathrm{FeAs}]
$$

Taking into account the expressions of constants $K_{1}$ and $K_{2}$, the three mass balances lead to the equation:

$$
[\mathrm{Fe}]_{\mathrm{t}}=[\mathrm{Fe}]+\frac{K_{1}\left([\mathrm{~s}]_{0}-[\mathrm{s}]_{\mathrm{f}}\right)[\mathrm{Fe}]}{1+\frac{K_{1}}{n_{1}}[\mathrm{Fe}]}+\frac{K_{2}[\mathrm{As}]_{0}[\mathrm{Fe}]}{1+\frac{K_{2}}{n_{2}}[\mathrm{Fe}]}
$$

from which the concentration of free Fe(III) hydroxide, [Fe], can be obtained by numerical solution. The variation of concentration of arsenic species in time is deduced straightforwardly from [Fe] using:

$$
[\mathrm{As}]=\frac{n_{2}[\mathrm{As}]_{0}}{n_{2}+K_{2}[\mathrm{Fe}]}
$$

whereas the COD level is calculated according to:

$$
[\mathrm{S}]=[\mathrm{S}]_{\mathrm{f}}+\frac{n_{1}\left([\mathrm{~S}]_{0}-[\mathrm{S}]_{\mathrm{f}}\right)}{n_{1}+K_{1}[\mathrm{Fe}]}
$$

The model required the values for parameters $K_{1}, K_{2}, n_{1}$, and $n_{2}$. The above model, assuming no interactions between the abatement of COD and As species, was applied to the set of data. Fig. 5 establishes the acceptable validity of the model for As concentrations ranging from $0.3 \mu \mathrm{g} / \mathrm{L}$ to $700 \mu \mathrm{g} / \mathrm{L}$.

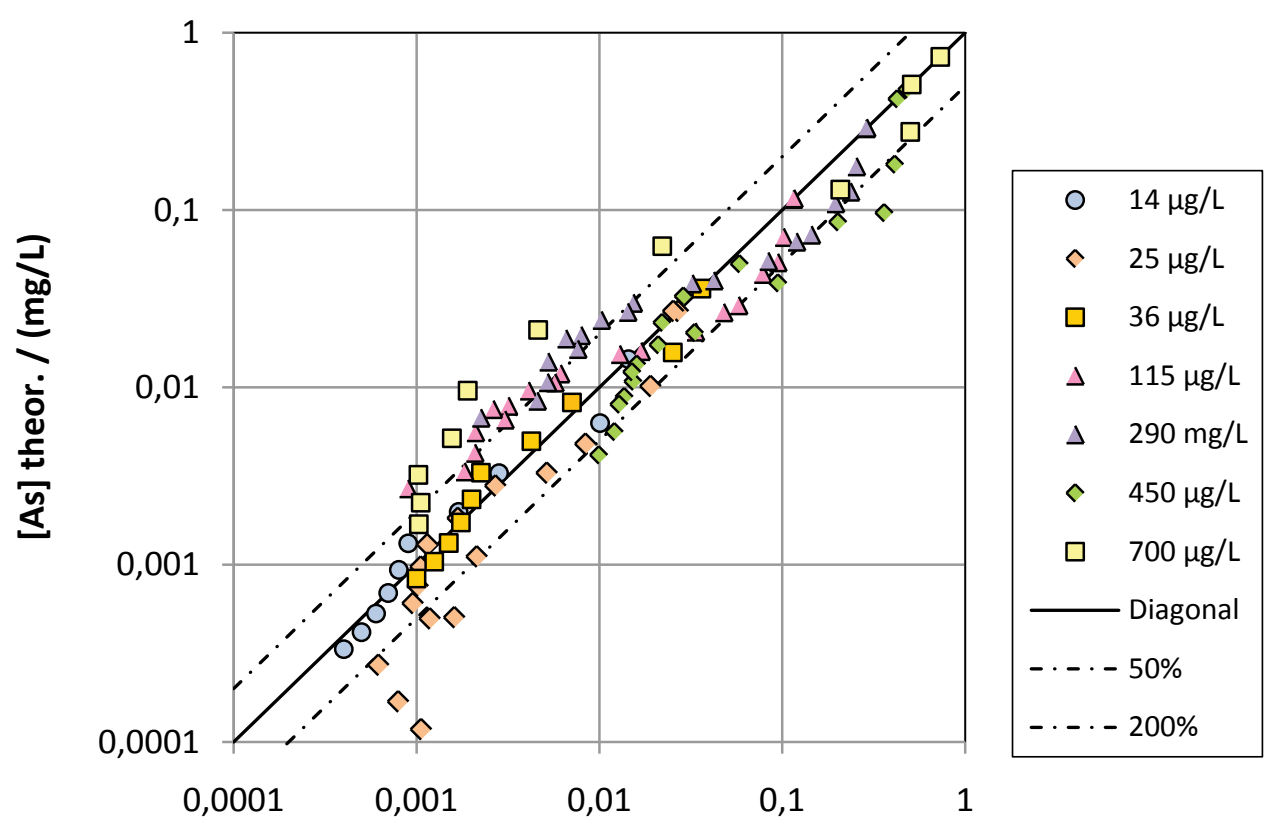

[As] $\exp . /(\mathrm{mg} / \mathrm{L})$

Figure 5. Validation of the model for As removal from As-enriched paper mill wastewater (rel. 12 and 13).

Most predicted values for the concentration lie between 50 and $200 \%$ of the experimental value. Taking into account the uncertainty in the experiments, in particular in the chemical analysis of As in quite a large range of concentration and the existing uncertainty in the values for the parameters $n_{2}$ and $K_{2}$, the approach can be considered as successful. Therefore, for the sample of 
industrial waste considered, the highly toxic salt added seems to be removed from the wastewater independently of the organic matter contained in the waste. In addition, the simple equations developed here are sufficient to model the waste treatment. Comparison of the experimental and predicted COD levels was not carried out since COD abatement was only slightly affected by the presence of As species, which was added in concentrations of nearly two orders below the COD level.

\section{Conclusions}

Arsenic species can be successfully removed from industrial waste by electrocoagulation using Fe electrodes. As(V) ions adsorb on Fe hydroxide in accordance with Langmuir-like adsorption isotherm. The parameters of the adsorption equilibrium could be estimated from previously published data dealing with the treatment of waters with low COD levels. This equilibrium could be incorporated into a more general model for the abatement of both As and COD, assuming no interaction in the treatment of the two pollution sources. In the example of industrial waste issued by a paper mill industry, the model was shown to hold, allowing a fairly accurate prediction of the As species. However, the approach may not be successful for industrial wastewaters containing oxidizing or reductive agents, which could change the chemical state of the arsenic salt and then affect its adsorption onto the Fe hydroxide particles. Whatever the model, a thorough characterization of the waste to be treated is required prior to designing the electrocoagulation process. For such reactive wastes, further characterization of their chemical behavior seems to be absolutely necessary.

Acknowledgements: The authors are indebted to S. Pontvianne for his thorough assistance in chemical analysis of the fractions collected.

\section{References}

[1] J.R. Parga, D.L. Cocke, J.L. Valenzuela, J.A. Gomes, M. Kesmez, G. Irwin, H. Moreno, M. Weir, J. Hazard. Mater. 124 (2005) 247-254.

[2] M. Leist, R.J. Casey, D. Caridi, J. Hazard. Mater. 76 (2000) 125-138.

[3] H.K. Hansen, P. Nunez, D. Raboy, I. Schippacasse, R. Grandon, Electrochim. Acta 52 (2007) 3464-3470.

[4] P. Ranta Kumar, S. Chaudhari, K.C. Khilar, S.P. Mahajan, Chemosphere 55 (2004) 1245-1252.

[5] J.A.G. Gomes, P. Daida, M. Kesmez, M. Weir, H. Moreno, J.R. Parga, G. Irwin, H. McWhinney, T. Grady, E. Peterson, D.L. Cocke, J. Hazard. Mater. 139 (2007) 220-231.

[6] G. Dodbiba, T. Nukaya, Y. Kamioka, Y. Tanimura, T. Fujita, Resour. Conserv. Recy. 53 (2009) 688-697.

[7] P. Canizares, F. Martinez, C. Jimenez, C. Saez, M.A. Rodrigo, J. Hazard. Mater. 151 (2008) 44-51.

[8] B. Merzouk, B. Gourich, A. Sekki, J.K. Madani, M. Chibane, J. Hazard. Mat. 164 (2009) 215222

[9] I. Zongo, J.P. Leclerc, H.A. Maiga, J. Wethe, F. Lapicque, Sep. Purif. Technol. 66 (2009) 159166.

[10] S. Zodi, J.N. Louvet, C. Michon, O. Potier, M.N. Pons, F. Lapicque, J.P. Leclerc, accepted in Chem. Eng. Proc. Proc. Intens.

[11] M. Khemis, J.P. Leclerc, G. Tanguy, G. Valentin, F. Lapicque, Chem. Eng. Sci. 61 (2006) 36023609.

[12] I. Zongo, A.H. Maiga, J. Wéthé, G. Valentin, J-P. Leclerc, G. Paternotte, F. Lapicque J. Hazard. Mater. 169 (2009) 70-76.

[13] R.B. Heslop and P.L. Robinson, Inorganic Chemistry, Elsevier, Amsterdam (1967). 
[14] R.C. Weast, Handbook of Chemistry and Physics, $76^{\text {th }}$ Edition CRC Press, Boca Raton (20052006).

[15] J.F. Martinez-Villafane, C. Montero-Ocampo, A.M. Garcia Lara, J. Hazard. Mater. B172 (2009) 1617-1622.

[16] A. Maldonado-Reyes, C. Montero-Ocampo, O. Solorio-Feria, J. Environ. Monit. 9 (2007) 1241-1247.

[17] P. Lakshmipathiraj, S. Prabhakar, G.B. Raju, Sep. Purif. Technol. 73 (2010) 114-121

(C) 2011 by the authors; licensee IAPC, Zagreb, Croatia. This article is an open-access article distributed under the terms and conditions of the Creative Commons Attribution license (http://creativecommons.org/licenses/by/3.0/) (cc) EY 